\title{
NEW INTEGRATION OF MCDM METHODS AND QFD IN THE SELECTION OF GREEN SUPPLIERS
}

\section{${ }^{1}$ Morteza YAZDANI, ${ }^{2}$ Sarfaraz HASHEMKHANI ZOLFANI, ${ }^{3}$ Edmundas Kazimieras ZAVADSKAS}

\author{
${ }^{1}$ Department of Business Management, Faculty of Social Sciences, \\ Universidad Europea de Madrid, 28670, Madrid, Spain \\ ${ }^{2}$ Technology Foresight Group, Department of Management, \\ Science and Technology, Amirkabir University of Technology (Tehran Polytechnic), \\ P.O. Box 1585-4413, Tehran, Iran \\ Institute for Futures Studies in Health, Health Services Management Research Center, \\ Kerman University of Medical Sciences, Kerman, Iran \\ ${ }^{3}$ Research Institute of Smart Building Technologies, Vilnius Gediminas \\ Technical University, Sauletekio al. 11, LT-10223 Vilnius, Lithuania \\ E-mails: ${ }^{1}$ morteza_yazdani21@yahoo.com; ${ }^{2}$ sa.hashemkhani@gmail.com; \\ 3edmundas.zavadskas@vgtu.lt (correspondingauthor)
}

Received 28 October 2015; accepted 09 March 2016

\begin{abstract}
Currently, topics of operations management and supply chain systems have been gaining more interest of researchers. Efficiency in supply chain activities and operations management firstly benefit organisations. One of the main operations in supply chain systems is the collaboration with selected suppliers. Various models have been proposed in terms of supplier evaluation and selection studies. The invention of a new integrated frame for the building of an effective supplier evaluation system is a multi-attribute task that consists of several factors as external and internal variables. This paper delivers a creative integrated model of supplier selection problem using SWARA, QFD and a new MCDM tool called WASPAS. This work considers customer attitudes in the process of supplier evaluation. To give more weight to customer requirements, a new SWARA method has been designed; additionally, QFD and the house of quality matrix have been used to transform customer requirements into the supplier evaluation index. Finally, WASPAS has been used to rate the performance of suppliers and present supplier ranking scores. Application of initiative ways to propose a systematic supplier selection problem has always been encouraged by supply chain managers. This topic has been addressed in this paper as well.
\end{abstract}

Keywords: green supplier selection, supply chain management (SCM), multiple criteria decision making (MCDM), SWARA, QFD, WASPAS.

JEL Classification: A12, C44, C80, D81. 


\section{Introduction}

Selection of suppliers for a typical supply chain system is an important task and one of the leading decision problems. In every manufacturing system that has a lot of properties, variables and tactics, many difficult and complex decision problems, such as supplier selection, must be solved. In addition, numerous factors, indexes and characteristics that have to be analysed by supply chain experts, depend on the whole system as well as external and internal variables. Supply chain designers have to draw on their knowledge and skills to define concepts, algorithms and models in order to optimise the performance of a system as well the system of supplier evaluation considering economic, social, governmental and environmental aspects. In the process of choosing an optimal supplier, many factors, including price, quality, delivery, production plan, facilities and some other specific sub-factors need to be taken into account, which sounds like a multiple criteria decision making (MCDM) problem (Hashemkhani Zolfani et al. 2016a, 2016b) Therefore, an efficient and systematic programme to facilitate the process of supplier selection is definitely a key issue in the supply chain management (SCM) structure.

In every MCDM problem, criteria can greatly affect the output of the evaluation system and specifically - supplier evaluation and selection. Traditional studies on supplier selection have concentrated broadly on aspects of supplier selection in terms of some internal and inter-organisational factors, without considering the opinion of their customers or customer requirements (CRs) (CRs are considered as a kind of external variables). Any stable supplier assessment system must consider the external environment of the whole supply chain and pay attention to the establishment of a clear understanding of customer needs, specifically - their subjective performance requirements. Hence, an improvement action is complementary to transit from the traditional approach (economic and general assessment of cost, efficiency, quality, lead time, etc.) to some new era of the supplier selection problem, which for instance highlights buyer satisfaction and the benefit of the stakeholders. In this case, a need for an instrument to connect customer and stakeholder attitudes to relevant supplier criteria is compulsory. This instrument is called the quality function deployment and utilises the house of quality matrix in order to make this fundamental connection (Bevilacqua et al. 2006; Büyüközkan et al. 2007; Bhattacharya et al. 2010; Dursun, Karsak 2013). Thus, the fundamental contribution of this paper from the technical viewpoint can be stated as the way to integrate QFD and a new weighting tool called SWARA, which has some preference of other weighting methods. One of the essential tasks in MCDM modelling is to explore new and logical ways to weight decision factors (attributes). Hence, it is understood that SWARA is preferred to usual weighting methods. To the best of our knowledge, this integration of QFD with SWARA is also new to the literature and no research project in this area has proposed it yet.

SWARA method acts differently than other weighting tools, such as AHP, Entropy, ANP and Delphi (Yang, Tzeng 2011; Kwong, Bai 2002). According to this method, the most significant criterion is given the first rank as the best, and the most trivial criterion is given the last rank. The overall ranks are demonstrated according to the mean value of ranks based on the decision of the group of experts. SWARA is beneficial for experts in the assessment of criteria and weights. The benefit is that each of them can deter- 
mine the importance of each criterion on their own. Afterwards, experts are able to sort the criteria from the first to the last considering the overall outcome (Vafaeipour et al. 2014). SWARA presents an opportunity for policy-makers to take decisions based on different situations and to prioritise criteria based on their desired needs and goals. On the same line, the method incorporates expert comments into the process of such crucial projects (Hashemkhani Zolfani 2015)

\section{Literature review}

The literature review of this article is presented in three sections: The first section is about general ideas regarding the impact of SCM on the economic importance of the green perspective in managing the environment and the world. The green SCM role in sustainability literature is considered in this section as well. The second section is about green SCM literature and its antecedent developments in other fields of research. Finally, the last section is dedicated to the integrated research, which focused on the combination of MCDM methods with SCM.

The importance of economic development and growth is obvious for each nation and is a key part of each government's activities. Environmental issues are involved the part dedicated to the sustainable growth, which is a fundamental consideration these days. The term "green growth" has been considered as major topic at the recent United Nations Conference on the Sustainable Development called Rio+20 (Fahimnia et al. 2015). Generally, organisations that are successful and efficient in the sustainable development are considerably influenced by the level of efficiency in the performance of supply chains, particularly, the green performance of supply chain members that have a significant impact on the overall green performance of organisations (Chithambaranathan et al. 2015). A greening supply chain is a new paradigm that has been developing in industries and organisations. It can make a considerable contribution to both the economic and environmental development. This general perspective has been named green or environmentally sustainable supply chain management (Varsei et al. 2014). This new trend has developed more line the Green Supply Chain Management (GSCM) concept an important approach to becoming environmentally sustainable (Shabani et al. 2014; Yang et al. 2013; HooBae et al. 2011). In this new GSCM concept, organisations attempt to work together and accomplish more in designing more innovations, incurring fewer expenditures, undertaking less risk, and achieving higher quality (Azadi et al. 2014). Many explanations have been offered in the investigation of the Green supply chain management (GSCM) (Vachon, Klassen 2006; Zhu et al. 2006, 2008; Min, Kim 2012) but one of the best-summarised definitions has been presented by Sarkis et al. 2011 and reads as follows:

GSCM can be defined as an incorporation of environmental issues and concerns into organisational activities taking place at different levels of the supply chain management system. It configures the application of environmental management principles to levels of a product's lifecycle, encompassing the design and material requirements, procurement and purchasing, manufacturing, packaging, logistics and distribution, end-user issues and final recycling to increase the competitive advantage of the company (Eltayeb 2011). The supply chain system can be considered green provided every member and 
feature of it work appropriately. Suppliers as strategic members of every supply chain should adopt the requirements of the focal company and customers. Hence, analysing and monitoring suppliers within a decisive frame is essential to improve green performance of suppliers (Lee 2009). In the last decade, green manufacturing or green supply chain concept has been growing dramatically among researchers, managers, environmentalists and others (Gunasekaran, Spalanzani 2012; Brockhaus et al. 2013). This is a developing trend among those companies, which make a connection between general green practices and their corporate strategies (Gunasekaran, Gallear 2012; Sarkis et al. 2011; Dubey et al. 2015).

Traditional supplier evaluation tools mainly concentrated on internal measures as economic and conventional factors in the evaluation process to improve organisational performance and maintain profits. Moreover, the used method and models included simple variables and parameters and, in other words, were not stable or robust enough to be globally developed. Many researchers and practitioners have already suggested and acquired MCDM and its integration in crisp, fuzzy, grey and group decision-making (GDM) environments to address supplier selection problems in traditional and green supply chain systems (Chai 2013; Govindan 2013). Among them, linear programmingbased approach (Ghodsypour, O’brien 1998), AHP (Kahraman et al. 2003; Pi, Low 2006; F. T. Chan, H. K. Chan 2010; Kilincci, Onal 2011), Grey Relational Analysis (GRA) (Yang, Cheng 2006), MOORA method (Karande, Chakraborty 2012; A. Baležentis, T. Baležentis 2011), and TOPSIS (Yazdani, Payam 2015) have been recognised as single approaches while hybrid or integrated models have been successfully applied to optimize supplier evolution process, including the combined analytical network process (ANP) and multi-objective mixed integer linear programming (MOMILP) (Demirtas, Üstün 2008), AHP-QFD combined approach (HooBae et al. 2011), "Vlse Kriterijumska Optimizacija Kompromisno Resenje” (VIKOR) (Yazdani, Graeml 2014) and "ELimination and Et Choice Translating Reality" (ELECTRE) (Chatterjee et al.2011), integrated VIKOR and ANP (Lixin et al. 2008), VIKOR method in fuzzy GDM environment (Sanayei et al. 2010), fuzzy QFD model (Amin, Razmi 2009), fuzzy preference ranking organisation method for enrichment evaluation (PROMETHEE) method (Chen et al. 2011), ELECTRE I algorithm in a GDM environment (Hatami-Marbini, Tavana 2011), grey-VIKOR (P. Chatterjee, R. Chatterjee 2012), COPRAS-Grey (Hashemkhani Zolfani et al. 2012) and fuzzy GDM approach using QFD model (Dursun, Karsak 2013), integrated SWOT analysis, adapted data envelopment analysis (DEA) and TOPSIS (Chen 2011) model, hybrid method using step-wise weight assessment ratio analysis (SWARA) and VIKOR methods (Alimardani et al. 2013), rough sets theory (RST) and multi-objective mixed integer programming (MOMIP)-based approach (Xia, Wu 2007), hybrid QFD method (Rajesh, Malliga 2013; Asadabadi 2014), and combined ANP and modified GRA method (Hashemi et al. 2015).

\section{Research methodology}

In this section, the proposed algorithm for rating and evaluation of suppliers is discussed and developed. At first, following the house of quality matrix in QFD process, customer requirements (CRs) and supplier evaluation criteria have been identified. For the 
purposes of this study, CRs covered the financial stability, environmental management system, waste disposal, management commitment, quality control systems, manufacturing, facility and reverse logistic for supplier criteria quality adoption, price, energy consumption, delivery speed, green design, re-use and recycle rate and production planning, which were the main elements of the QFD model. The crucial task of QFD was to translate customer needs to engineering and technical parameters to be usable and understandable for supplier evaluation. Then, to achieve relative importance of CRs, the SWARA method has been employed. The CRs and related weights (Table 1) have been derived based on expert opinions and approaches. In the next phase, purchasing experts have detected the relationship between CRs. Normalised weights of criteria have then been used as an input for the WASPAS process. In the third phase, WASPAS technique has been used to solve the decision problem and finally deliver the ranking of all suppliers.

\subsection{SWARA method}

SWARA is a new and interesting weighing discipline. It is a suitable method for the subjects with priorities that had been specified earlier, according to situations. SWARA is able to estimate expert opinions regarding the importance ratio of criteria. The procedure for the determination of weights by SWARA as mathematical stepwise analysis can be expressed as follows:

Step 1 - All criteria should be sorted based on expert ideas (Zavadskas, Vilutienè 2006; Zavadskas et al. 2008; 2010).

Step 2 - From the second criterion, the comparative importance of the average value $s_{j}$ should be determined as follows: the relative importance of the criterion $j$ in relation to the previous $(j-1)$ criterion (Stanujkic et al. 2015).

Step 3 - Determine the coefficient $k_{j}$ :

$$
k_{j}=\left\{\begin{array}{cc}
1 & j=1 \\
s_{j}+1 & j>1
\end{array} .\right.
$$

Step 4 - Determine the recalculated weight $w_{j}$ :

$$
w_{j}=\left\{\begin{array}{cc}
1 & j=1 \\
\frac{x_{j-1}}{k_{j}} & j>1
\end{array} .\right.
$$

Step 5 - The final step in the calculation of criteria weights:

$$
q_{j}=\frac{w_{j}}{\sum_{k=1}^{n} w_{j}},
$$

where $q_{j}$ denotes the relative weight of the criterion $j$. 


\subsection{QFD method}

QFD is an engineered tool, which transforms the requirements of end-users and customers into specific and understandable characteristics of the product design and production process. QFD transformations are handled by a matrix displaying the relationships between the voice of the customers and the quality characteristics. It is known as the House of Quality (HoQ) matrix, which expresses the relationship between the CRs (WHATs) and the supplier attributes (HOWs) (Chen et al. 2005). The general QFD model incorporates the following characteristics in the HoQ: (a) WHATs matrix, (b) HOWs matrix, (c) the relationship matrix between WHATs and HOWs, (d) the relative importance or weights of WHATs, (e) the interrelationship between HOWs, and (f) weights of HOWs (Khademi-Zare et al. 2010). In this study, QFD has been applied to connect the supplier evaluation criteria to the customer requirements to obtain more reliable and global decision objectives.

The general steps for the implementation of the QFD model are as follow:

Step 1 - To identify the WHATs.

Step 2 - To define the HOWs.

Step 3 - To assign priority weights to the CRs. In this paper, this process is done using the SWARA method.

Step 4 - To release the relationship matrix (or the HoQ resulting matrix) using the knowledge of the decision maker to build this relationship matrix using a four point scale: weak relationship (1), moderate relationship (3), strong relationship (6) and very strong relationship (9). Users can address their judgement using moderate values as 2 , $4,5,7$ and 8 . These relationships indicate how supplier evaluation criteria can quantitatively satisfy the CRs.

Step 5 - To compute the overall priorities of supplier attributes. In the study case, these weights are interpreted as the relative weights of the supplier selection criteria. Suppose that $n$ supplier selection criteria are used to satisfy $m$ CRs. Then, the degree of importance (weight) $w_{j}$ of the $j$-th supplier selection criterion, with $j=1, \ldots, n$ is computed as follows:

$$
w_{j}=\sum_{i=1}^{m} R_{i j} C_{i},
$$

where, for $j=1, \ldots, n$ and $i=1, \ldots, m, R_{i j}$ denotes the relationship between the $j$-th supplier selection criteria and the $i$-th $\mathrm{CR}$ and $C_{i}$ represents the weight of $i$-th CR computed using the SWARA method. The normalised weight of each supplier $\tilde{w}_{j}$ is computed by the following equation:

$$
\tilde{w}_{j}=\frac{w_{j}}{\sum_{j=1}^{n} w_{j}} \text {. }
$$




\subsection{Weighted Aggregated Sum Product Assessment (WASPAS)}

Weighted Aggregated Sum Product Assessment (WASPAS) is one of the most recently developed MCDM tools. It is the mixture of two MCDM approaches, i.e. the Weighted Sum Model (WSM) and the Weighted Product Model (WPM). The following formulas report the ranking of decision alternatives:

$$
\left[\begin{array}{cccc}
x_{11} & x_{12} & \ldots & x_{1 n} \\
x_{21} & x_{22} & \ldots & x_{2 n} \\
\ldots & \ldots & \ldots & \ldots \\
x_{m 1} & x_{m 2} & \ldots & x_{m n}
\end{array}\right]
$$

where $n$ is the number of evaluation criteria and $j=1, \ldots, n, x_{i j}$ is the performance rating of the $I$ alternative upon the $j$-th decision criterion. This decision matrix is normalised using the following equations, where the normalised generic element of the decision matrix is denoted by $\tilde{x}_{i j}$ :

For benefit attributes:

$$
\tilde{x}_{i j}=\frac{x_{i j}}{\max _{i} x_{i j}}, j=1, \ldots, n ; i=1, \ldots, m .
$$

For non-benefit attributes:

$$
\tilde{x}_{i j}=\frac{\min _{i} x_{i j}}{x_{i j}}, j=1, \ldots, n ; i=1, \ldots, m .
$$

To compute WASPAS weighted normalised decision matrix, the following two actions must be performed. The first one is assigned to the summarization process of WASPAS:

$$
\tilde{\tilde{x}}_{i j, \text { sum }}=\tilde{x}_{i j} w_{j}, j=1, \ldots, n ; i=1, \ldots, m
$$

and for the multiplication part;

$$
\tilde{\tilde{x}}_{i j, \text { mult }}=\tilde{x}_{i j}^{w_{j}}, \text { where } j=1, \ldots, n ; i=1, \ldots, m .
$$

A joint generalised criterion of weighted aggregation of additive and multiplicative methods can be then proposed as follows:

$$
Q_{i}=0.5 \sum_{j=1}^{n} \tilde{\tilde{x}}_{i j, \text { sum }}+0.5 \prod_{j=1}^{n} \tilde{\tilde{x}}_{i j, \text { mult }}, j=1, \ldots, n ; i=1, \ldots, m .
$$

In order to increase the ranking accuracy and effectiveness of the decision-making process, using the WASPAS method, a more generalised equation for determining the total relative importance of the alternatives can be employed (Zavadskas et al. 2012):

$$
Q_{i}^{\lambda}=\lambda \sum_{j=1}^{n} \tilde{\tilde{x}}_{i j, \text { sum }}+(1-\lambda) \prod_{j=1}^{n} \tilde{\tilde{x}}_{i j, m u l t}
$$


Finally, the candidate alternatives can be ranked based on the $Q$ - values, i.e. the best alternative would be the one having the highest $Q$-value. When the value of $\lambda$ is 0 , the WASPAS method coincides with WPM, while for $\lambda=1$, WASPAS corresponds to WSM. Recently, researchers have been using WASPAS and trying to increase its applicability.

\section{Results and discussion}

The proposed model for supplier evaluation has been implemented in the Steel Alborz Company in Iran, which is active in the stainless steel industry. This company is one of the most famous companies in the Middle East with export to more than 40 countries in different continents. In this section, SWARA has been primarily applied for evaluating the relative importance of each customer requirement. Experts have considered eight requirements and delivered weights and relative importance of each requirement following the SWARA process. The results of SWARA weights are exhibited in Table 1. The financial stability has been the most important requirement in this study in terms of the expert attitude.

Table 1. SWARA outcomes as assigned weights for CRs

\begin{tabular}{lcccc}
\hline \multicolumn{1}{c}{$\begin{array}{c}\text { Customer } \\
\text { requirements }\end{array}$} & $\begin{array}{c}\text { Comparative importance } \\
\text { of the average value } S_{j}\end{array}$ & $\begin{array}{c}\text { Coefficient } \\
K_{j}=1+S_{j}\end{array}$ & $\begin{array}{c}\text { Recalculated } \\
\text { weight } w_{j}\end{array}$ & $\begin{array}{c}\text { Final } \\
\text { weight } q_{j}\end{array}$ \\
\hline Financial stability (FS) & - & 1 & 1 & $\mathbf{0 . 2 1 2}$ \\
\hline $\begin{array}{l}\text { Environmental } \\
\text { management system } \\
\text { (EMS) }\end{array}$ & 0.2 & 1.2 & 0.833 & $\mathbf{0 . 1 7 6}$ \\
\hline $\begin{array}{l}\text { Waste disposal program } \\
\text { (WDP) }\end{array}$ & 0.15 & 1.15 & 0.725 & $\mathbf{0 . 1 5 3}$ \\
\hline $\begin{array}{l}\text { Management } \\
\text { commitment (MC) }\end{array}$ & 0.2 & 1.2 & 0.604 & $\mathbf{0 . 1 2 8}$ \\
\hline $\begin{array}{l}\text { Quality control systems } \\
\text { (QCS) }\end{array}$ & 0.18 & 1.18 & 0.512 & $\mathbf{0 . 1 0 8}$ \\
\hline Manufacturing (M) & 0.25 & 1.25 & 0.409 & $\mathbf{0 . 0 8 7}$ \\
\hline Facility (F) & 0.15 & 1.15 & 0.356 & $\mathbf{0 . 0 7 5}$ \\
\hline Reverse logistic (RL) & 0.24 & 1.24 & 0.287 & $\mathbf{0 . 0 6 1}$ \\
\hline
\end{tabular}

The next section is to reach the main weights of supplier criteria. This task has been handled using the QFD model and the house of quality matrix. In fact, experts should have determined how a typical supplier criterion could satisfy customer requirement. This operation is shown in Table 2. As demonstrated at the end of the QFD process, the weights and normalised weights of the decision criteria have been produced using Equations 4 and 5. 
Table 2. HoQ matric and QFD procedure for the weight of a supplier criterion

\begin{tabular}{|c|c|c|c|c|c|c|c|c|}
\hline \multirow[b]{2}{*}{$\begin{array}{l}\text { HOWs } \\
\text { (Require- } \\
\text { ments) }\end{array}$} & \multicolumn{7}{|c|}{ WHATs (Criteria) } & \multirow{2}{*}{$\begin{array}{c}\text { Weight of } \\
\text { requirements } \\
\text { by SWARA }\end{array}$} \\
\hline & $\begin{array}{l}\text { Quality } \\
\text { adoption }\end{array}$ & Price & $\begin{array}{l}\text { Energy } \\
\text { consump- } \\
\text { tion }\end{array}$ & $\begin{array}{c}\text { Delivery } \\
\text { speed }\end{array}$ & $\begin{array}{l}\text { Green } \\
\text { design }\end{array}$ & $\begin{array}{l}\text { Re-use, } \\
\text { re-cycle } \\
\text { rates }\end{array}$ & $\begin{array}{l}\text { Produc- } \\
\text { tion plan- } \\
\text { ning }\end{array}$ & \\
\hline $\begin{array}{l}\text { Financial } \\
\text { stability (FS) }\end{array}$ & 7 & 5 & 6 & 6 & 4 & 2 & 5 & 0.212 \\
\hline $\begin{array}{l}\text { Environmental } \\
\text { management } \\
\text { system (EMS) }\end{array}$ & 6 & 3 & 3 & 4 & 5 & 4 & 3 & 0.176 \\
\hline $\begin{array}{l}\text { Waste disposal } \\
\text { program } \\
\text { (WDP) }\end{array}$ & 4 & 8 & 7 & 4 & 1 & 2 & 6 & 0.153 \\
\hline $\begin{array}{l}\text { Management } \\
\text { commitment } \\
(\mathrm{MC})\end{array}$ & 5 & 3 & 4 & 2 & 4 & 5 & 5 & 0.128 \\
\hline $\begin{array}{l}\text { Quality } \\
\text { control } \\
\text { systems } \\
\text { (QCS) }\end{array}$ & 6 & 2 & 2 & 3 & 4 & 4 & 7 & 0.108 \\
\hline $\begin{array}{l}\text { Manufacturing } \\
\text { (M) }\end{array}$ & 5 & 3 & 4 & 5 & 2 & 1 & 6 & 0.087 \\
\hline Facility (F) & 8 & 5 & 6 & 6 & 3 & 2 & 7 & 0.075 \\
\hline $\begin{array}{l}\text { Reverse } \\
\text { logistic (RL) }\end{array}$ & 3 & 6 & 5 & 4 & 6 & 4 & 5 & 0.061 \\
\hline $\begin{array}{l}\text { Weight of } \\
\text { criteria }\end{array}$ & 5.66 & 4.41 & 4.70 & 4.30 & 3.59 & 2.99 & 5.25 & 30.903 \\
\hline $\begin{array}{l}\text { Normalized } \\
\text { weight of } \\
\text { criteria }\end{array}$ & 0.183 & 0.143 & 0.152 & 0.139 & 0.116 & 0.097 & 0.170 & \\
\hline
\end{tabular}

At this level, weights of all criteria and performance rating of candidate alternatives had to be obtained. Weights have been calculated by the SWARA-QFD integrated approach. So, for the performance of suppliers, Table 3 has been provided by experts based on qualitative scales. Then, to translate the qualitative variable, Table 4 as a reference datasheet has been used and also the initial decision matrix for applying WASPAS (Table 5). 
Table 3. Supplier performance rating using qualitative scales

\begin{tabular}{cccccccc}
\hline Alternatives & $\begin{array}{c}\text { Quality } \\
\text { adoption }\end{array}$ & Price & $\begin{array}{c}\text { Energy } \\
\text { consumption }\end{array}$ & $\begin{array}{c}\text { Delivery } \\
\text { speed }\end{array}$ & $\begin{array}{c}\text { Green } \\
\text { design }\end{array}$ & $\begin{array}{c}\text { Re-use, } \\
\text { re-cycle } \\
\text { rates }\end{array}$ & $\begin{array}{c}\text { Production } \\
\text { planning }\end{array}$ \\
\hline$S_{1}$ & First & Second & High & So fast & Harmful & $70 \%$ & Excellent \\
\hline$S_{2}$ & Fourth & Fifth & Reasonable & Fast & Harmful & $75 \%$ & Suitable \\
\hline$S_{3}$ & Sixth & Sixth & High & Middle & Harmful & $65 \%$ & Suitable \\
\hline$S_{4}$ & First & $\begin{array}{c}\text { Most } \\
\text { expensive }\end{array}$ & High & So fast & Compatible & $85 \%$ & Excellent \\
\hline$S_{5}$ & Fifth & Fourth & Reasonable & Middle & Harmful & $75 \%$ & Suitable \\
\hline$S_{6}$ & First & Third & High & Fast & Compatible & $85 \%$ & Excellent \\
\hline
\end{tabular}

Table 4. References for translating qualitatie data to quantitative values

\begin{tabular}{|c|c|c|c|c|c|c|c|c|c|c|c|}
\hline \multicolumn{2}{|c|}{ Quality } & \multicolumn{2}{|c|}{ Price } & \multicolumn{2}{|c|}{$\begin{array}{c}\text { Energy } \\
\text { consumption }\end{array}$} & \multicolumn{2}{|c|}{$\begin{array}{l}\text { Delivery } \\
\text { speed }\end{array}$} & \multicolumn{2}{|c|}{ Green design } & \multicolumn{2}{|c|}{$\begin{array}{c}\text { Prod. } \\
\text { planning }\end{array}$} \\
\hline 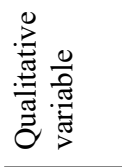 & 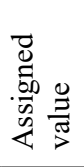 & 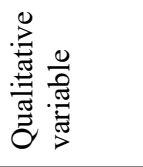 & 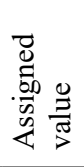 & 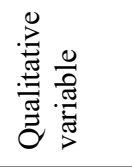 & 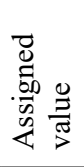 & 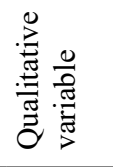 & 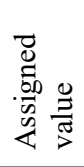 & 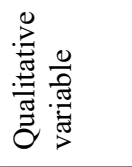 & 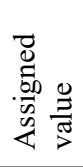 & 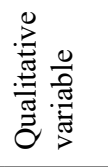 & 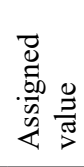 \\
\hline First & 10 & $\begin{array}{l}\text { Most exp. } \\
\text { (First) }\end{array}$ & 10 & High & 8 & So fast & 10 & $\begin{array}{l}\text { Compat- } \\
\text { ible }\end{array}$ & 8 & $\begin{array}{l}\text { Excel- } \\
\text { lent }\end{array}$ & 8 \\
\hline Second & 8 & Second & 8 & $\begin{array}{l}\text { Reason- } \\
\text { able }\end{array}$ & 6 & Fast & 8 & $\begin{array}{c}\text { Low } \\
\text { harmful }\end{array}$ & 6 & $\begin{array}{l}\text { Suit- } \\
\text { able }\end{array}$ & 6 \\
\hline Third & 6 & Third & 6 & Low & 4 & Middle & 6 & $\begin{array}{l}\text { Average } \\
\text { harmful }\end{array}$ & 4 & Weak & 4 \\
\hline Forth & 4 & Forth & 4 & $\begin{array}{l}\text { Very } \\
\text { low }\end{array}$ & 2 & Low & 4 & Harmful & 2 & $\begin{array}{l}\text { Zero } \\
\text { plan }\end{array}$ & 2 \\
\hline Fifth & 2 & Fifth & 2 & & & $\begin{array}{l}\text { Very } \\
\text { low }\end{array}$ & 2 & & & & \\
\hline Sixth & 1 & Sixth & 1 & & & & & & & & \\
\hline
\end{tabular}

Table 5. Converted qualitative data of suppliers for the evaluation of the process (the initial decision matrix)

\begin{tabular}{cccccccc}
\hline Alternative & $\begin{array}{c}\text { Quality } \\
\text { adoption }\end{array}$ & Price & $\begin{array}{c}\text { Energy } \\
\text { consumption }\end{array}$ & $\begin{array}{c}\text { Delivery } \\
\text { speed }\end{array}$ & $\begin{array}{c}\text { Green } \\
\text { design }\end{array}$ & $\begin{array}{c}\text { Re-use, } \\
\text { re-cycle rates }\end{array}$ & $\begin{array}{c}\text { Production } \\
\text { planning }\end{array}$ \\
\hline $\mathrm{S}_{1}$ & 10 & 8 & 8 & 10 & 2 & 0.7 & 8 \\
\hline $\mathrm{S}_{2}$ & 4 & 2 & 6 & 8 & 2 & 0.75 & 6 \\
\hline $\mathrm{S}_{3}$ & 1 & 1 & 8 & 6 & 2 & 0.65 & 6 \\
\hline $\mathrm{S}_{4}$ & 10 & 10 & 8 & 10 & 8 & 0.85 & 8 \\
\hline $\mathrm{S}_{5}$ & 2 & 4 & 6 & 6 & 2 & 0.75 & 6 \\
\hline $\mathrm{S}_{6}$ & 10 & 6 & 8 & 8 & 8 & 0.85 & 8 \\
\hline
\end{tabular}


The next step to solve the supplier evaluation problem is to follow the WASPAS algorithm. The structure and step-wise procedure of WASPAS have been introduced in Section 2.3. First of all, a normalised decision matrix is required. To obtain a normalised decision matrix, Equations 7 and 8 have to be used for the benefit and non-benefit criteria. For this work, all of the criteria except the price and resource consumption have been included in the category of the benefit criteria. Table 6 exhibits the normalised decision matrix.

Thereafter, weighted normalised supplier matrix must be achieved. As stated earlier, in the algorithm of WASPAS, the weighted normalised decision matrix has been composed of two concepts of MCDM - the weighted summation method and the weighted multiplication method. Those formulas are introduced as Equations 7 and 8. The weighted normalised supplier matrix is pictured in Table 7 .

Table 6. Normalised matrix for supplier evaluation

\begin{tabular}{cccccccc}
\hline Alternatives & $\begin{array}{c}\text { Quality } \\
\text { adoption }\end{array}$ & Price & $\begin{array}{c}\text { Energy } \\
\text { consumption }\end{array}$ & $\begin{array}{c}\text { Delivery } \\
\text { speed }\end{array}$ & $\begin{array}{c}\text { Green } \\
\text { design }\end{array}$ & $\begin{array}{c}\text { Re-use, } \\
\text { re-cycle rates }\end{array}$ & $\begin{array}{c}\text { Production } \\
\text { planning }\end{array}$ \\
\hline Supplier 1 & 1 & 0.125 & 0.75 & 1 & 0.25 & 0.82 & 1 \\
\hline Supplier 2 & 0.4 & 0.5 & 1 & 0.8 & 0.25 & 0.88 & 0.75 \\
\hline Supplier 3 & 0.1 & 1 & 0.75 & 0.6 & 0.25 & 0.76 & 0.75 \\
\hline Supplier 4 & 1 & 0.1 & 0.75 & 1 & 1 & 1.00 & 1 \\
\hline Supplier 5 & 0.2 & 0.25 & 1 & 0.6 & 0.25 & 0.88 & 0.75 \\
\hline Supplier 6 & 1 & 0.17 & 0.75 & 0.8 & 1 & 1.00 & 1 \\
\hline
\end{tabular}

Table 7. Weighted normalised decision matrix for suppliers

\begin{tabular}{cccccccc}
\hline Alternatives & $\begin{array}{c}\text { Quality } \\
\text { adoption }\end{array}$ & Price & $\begin{array}{c}\text { Energy } \\
\text { consumption }\end{array}$ & $\begin{array}{c}\text { Delivery } \\
\text { speed }\end{array}$ & $\begin{array}{c}\text { Green } \\
\text { design }\end{array}$ & $\begin{array}{c}\text { Re-use, } \\
\text { re-cycle rates }\end{array}$ & $\begin{array}{c}\text { Production } \\
\text { planning }\end{array}$ \\
\hline \multicolumn{7}{c}{ Weighted normalised (Summarization section) } & matrix of WASPAS \\
\hline Supplier 1 & 0.183 & 0.018 & 0.114 & 0.139 & 0.029 & 0.08 & 0.17 \\
\hline Supplier 2 & 0.073 & 0.071 & 0.152 & 0.111 & 0.029 & 0.085 & 0.128 \\
\hline Supplier 3 & 0.018 & 0.143 & 0.114 & 0.083 & 0.029 & 0.074 & 0.128 \\
\hline Supplier 4 & 0.183 & 0.014 & 0.114 & 0.139 & 0.116 & 0.097 & 0.17 \\
\hline Supplier 5 & 0.037 & 0.036 & 0.152 & 0.083 & 0.029 & 0.085 & 0.128 \\
\hline Supplier 6 & 0.183 & 0.024 & 0.114 & 0.111 & 0.116 & 0.097 & 0.17 \\
\hline & & Weighted normalised (Multiplication section) matrix of WASPAS & \\
\hline Supplier 1 & 1 & 0.743 & 0.957 & 1 & 0.851 & 0.981 & 1 \\
\hline Supplier 2 & 0.846 & 0.906 & 1 & 0.969 & 0.851 & 0.988 & 0.952 \\
\hline Supplier 3 & 0.656 & 1 & 0.957 & 0.931 & 0.851 & 0.974 & 0.952 \\
\hline Supplier 4 & 1 & 0.72 & 0.957 & 1 & 1 & 1 & 1 \\
\hline Supplier 5 & 0.745 & 0.82 & 1 & 0.931 & 0.851 & 0.988 & 0.952 \\
\hline Supplier 6 & 1 & 0.774 & 0.957 & 0.969 & 1 & 1 & 1 \\
\hline
\end{tabular}


Table 8. Ranking of suppliers by WASPAS and different values of $\lambda$

\begin{tabular}{lcccccccccc}
\hline \multirow{2}{*}{ Alternatives } & \multicolumn{7}{c}{ Rank of WASPAS for suppliers } \\
\cline { 2 - 12 } & $\lambda=0.1$ & $\lambda=0.2$ & $\lambda=0.3$ & $\lambda=0.4$ & $\lambda=0.5$ & $\lambda=0.6$ & $\lambda=0.7$ & $\lambda=0.8$ & $\lambda=0.9$ \\
\hline Supplier 1 & 3 & 3 & 3 & 3 & 3 & 3 & 3 & 3 & 3 \\
\hline Supplier 2 & 4 & 4 & 4 & 4 & 4 & 4 & 4 & 4 & 4 \\
\hline Supplier 3 & 5 & 5 & 5 & 5 & 5 & 5 & 5 & 5 & 5 \\
\hline Supplier 4 & 2 & 2 & 2 & 2 & 2 & 2 & 1 & 1 & 1 \\
\hline Supplier 5 & 6 & 6 & 6 & 6 & 6 & 6 & 6 & 6 & 6 \\
\hline Supplier 6 & 1 & 1 & 1 & 1 & 1 & 1 & 2 & 2 & 2 \\
\hline
\end{tabular}

To finalise the process of supplier selection through the WASPAS method, Equation 12 has been used. Based on this equation, the values of $\mathrm{Q}$ have been computed and the supplier ranking has been generated. Table 8 indicates the ranking of suppliers. Normally the WASPAS optimal ranking score (equation 11) is expressed by $\lambda=0.5$ According to this table, the supplier order preference is as given below:

Supplier $6>$ supplier $4>$ supplier $1>$ supplier $2>$ supplier $3>$ supplier 5 , supplier 4 is the favourite candidate while supplier 5 is the worst one among all. However, in this work, a different value of $\lambda$ (Table 8 ) has slightly changed the ranking of suppliers. In addition, except for a little change in $\lambda=0.7, \lambda=0.8$ and $\lambda=0.9$ rankings, the other ranking scores have remained the same, demonstrating the stability of the proposed method and WASPAS.

\section{Conclusions}

Supplier selection has been accomplished based on internal and external aspects. During the assessment of suppliers, external variables, such as customer needs and stakeholder attitudes had to be satisfied. On the other hand, suppliers have been analysed considering economic, environmental and other factors of the system. This paper has elaborated on a new structure to appraise suppliers according to a model, which connects supplier evaluation attributes to required customer values using the house of quality matrix and the QFD model. Customer requirements are defined and then experts attempt to connect supplier attributes by a rating system. To be meaningful and to catch the effect of customer importance, weights of customer requirements have been generated using a new weighting method SWARA. At the end of this stage, normalised weights of each decision attribute have been obtained. For prioritisation and getting the ranking of suppliers, WASPAS method has been developed. WASPAS enhances the chance of more reliable and optimal values. In this work, a supplier selection problem has been undertaken within a green supply chain system and so some green measures have been presented to conduct the QFD evaluation process. Planning, organising and evaluating the green supply chain operations are particularly critical issues in today's competitive circumstances. Due to this, the importance of green suppliers as one of the substantial elements of a supply chain and their standard assessment has been gaining more atten- 
tion of managers. Through this research, the authors of this article have indicated the possibility to integrate the QFD approach, SWARA weighting and WASPAS methods to reward proactive suppliers and eliminate or reform the defective ones. Although the proposed model has the ability to be implemented in the industry or any other sector, some limitations can be named. Provided users and experts indicate their judgements during the decision process using linguistic variables, fuzzy QFD and fuzzy MCDM must be deployed. Interdependency between decision variables and customer factors can possibly be resolved using the ANP or DEMATEL techniques. Moreover, the group decision-making framework can be addressed for future research perspectives.

\section{References}

Alimardani, M.; Hashemkhani Zolfani, S.; Aghdaie, M. H.; Tamošaitienė, J. 2013. A novel hybrid SWARA and VIKOR methodology for supplier selection in an agile environment, Technological and Economic Development of Economy 19(3): 533-548.

http://dx.doi.org/10.3846/20294913.2013.814606

Amin, S. H.; Razmi, J. 2009. An integrated fuzzy model for supplier management: a case study of ISP selection and evaluation, Expert systems with applications 36(4): 8639-8648.

http://dx.doi.org/10.1016/j.eswa.2008.10.012

Asadabadi, M. 2014. A hybrid QFD-based approach in addressing supplier selection problem in product improvement process, International Journal of Industrial Engineering Computations 5(4): 543-560. http://dx.doi.org/10.5267/j.ijiec.2014.7.005

Azadi, M.; Shabani, A.; Khodakarami, M.; Farzipoor Saen, R. 2014. Planning in feasible region by two-stage target-setting DEA methods: an application in green supply chain management of public transportation service providers, Transportation Research Part E: Logistics and Transportation Review 70: 324-338. http://dx.doi.org/10.1016/j.tre.2014.07.009

Baležentis, A.; Baležentis, T. 2011. An innovative multi-criteria supplier selection based on twotuple MULTIMOORA and hybrid data, Economic Computation and Economic Cybernetics Studies and Research 45(2): 37-56.

Bevilacqua, M.; Ciarapica, F. E.; Giacchetta, G. 2006. A fuzzy-QFD approach to supplier selection, Journal of Purchasing and Supply Management 12(1): 14-27.

http://dx.doi.org/10.1016/j.pursup.2006.02.001

Bhattacharya, A.; Geraghty, J.; Young, P. 2010. Supplier selection paradigm: An integrated hierarchical QFD methodology under multiple-criteria environment, Applied Soft Computing 10(4): 1013-1027. http://dx.doi.org/10.1016/j.asoc.2010.05.025

Brockhaus, S.; Kersten, W.; Knemeyer, A. M. 2013. Where do we go from here? Progressing sustainability implementation efforts across supply chains, Journal of Business Logistics 34(2): 167-182. http://dx.doi.org/10.1111/jbl.12017

Büyüközkan, G.; Feyzioğlu, O.; Ruan, D. 2007. Fuzzy group decision-making to multiple preference formats in quality function deployment, Computers in Industry 58(5): 392-402.

http://dx.doi.org/10.1016/j.compind.2006.07.002

Chai, J.; Liu, J. N.; Ngai, E. W. 2013. Application of decision-making techniques in supplier selection: a systematic review of literature, Expert Systems with Applications 40(10): 3872-3885. http://dx.doi.org/10.1016/j.eswa.2012.12.040

Chan, F. T.; Chan, H. K. 2010. An AHP model for selection of suppliers in the fast changing fashion market, The International Journal of Advanced Manufacturing Technology 51(9-12): 1195-1207. http://dx.doi.org/10.1007/s00170-010-2683-6 
Chatterjee, P.; Chatterjee, R. 2012. Supplier evaluation in manufacturing environment using compromise ranking method with grey interval numbers, International Journal of Industrial Engineering Computations 3(3): 393-402. http://dx.doi.org/10.5267/j.ijiec.2011.12.007

Chatterjee, P.; Mukherjee, P.; Chakraborty, S. 2011. Supplier selection using compromise ranking and outranking methods, Journal of Industrial Engineering International 7(14): 61-73.

Chithambaranathan, P.; Subramanian, N.; Gunasekaran, A.; Palaniappan, P. K. 2015. Service supply chain environmental performance evaluation using grey based hybrid MCDM approach, International Journal of Production Economics 166: 163-176.

http://dx.doi.org/10.1016/j.ijpe.2015.01.002

Chen, Y.; Fung, R. Y. K.; Tang, J. 2005. Fuzzy expected value modelling approach for determining target values of engineering characteristics in QFD, International Journal of Production Research 43(17): 3583-3604 http://dx.doi.org/10.1080/00207540500032046

Chen, Y. J. 2011. Structured methodology for supplier selection and evaluation in a supply chain, Information Sciences 181(9): 1651-1670. http://dx.doi.org/10.1016/j.ins.2010.07.026

Chen, Y. H.; Wang, T. C.; Wu, C. Y. 2011. Strategic decisions using the fuzzy PROMETHEE for IS outsourcing, Expert Systems with Applications 38(10): 13216-13222.

http://dx.doi.org/10.1016/j.eswa.2011.04.137

Demirtas, E. A.; Üstün, Ö. 2008. An integrated multi-objective decision making process for supplier selection and order allocation, Omega 36(1): 76-90.

http://dx.doi.org/10.1016/j.omega.2005.11.003

Dubey, R.; Gunasekaran, A.; Papadopoulos, T.; Childe, S. J. 2015. Green supply chain management enablers: mixed methods research, Sustainable Production and Consumption 4: 72-88. http://dx.doi.org/10.1016/j.spc.2015.07.001

Dursun, M.; Karsak, E. E. 2013. A QFD-based fuzzy MCDM approach for supplier selection, Applied Mathematical Modelling 37(8): 5864-5875. http://dx.doi.org/10.1016/j.apm.2012.11.014

Eltayeb, T. K.; Zailani, S.; Ramayah, T. 2011. Green supply chain initiatives among certified companies in Malaysia and environmental sustainability: investigating the outcomes, Resources, conservation and recycling 55(5): 495-506. http://dx.doi.org/10.1016/j.resconrec.2010.09.003

Fahimnia, B.; Sarkis, J.; Eshragh, A. 2015. A tradeoff model for green supply chain planning: a leanness-versus-greenness analysis, Omega 54: 173-190.

http://dx.doi.org/10.1016/j.omega.2015.01.014

Ghodsypour, S. H.; O’Brien, C. 1998. A decision support system for supplier selection using an integrated analytic hierarchy process and linear programming, International Journal of Production Economics 56: 199-212. http://dx.doi.org/10.1016/S0925-5273(97)00009-1

Govindan, K.; Rajendran, S.; Sarkis, J.; Murugesan, P. 2013. Multi criteria decision making approaches for green supplier evaluation and selection: a literature review, Journal of Cleaner Production 98: 66-83. http://dx.doi.org/10.1016/j.jclepro.2013.06.046

Gunasekaran, A.; Gallear, D. 2012. Special issue on sustainable development of manufacturing and services, International Journal of Production Economics 140(1): 1-6.

http://dx.doi.org/10.1016/j.ijpe.2012.07.005

Gunasekaran, A.; Spalanzani, A. 2012. Sustainability of manufacturing and services: investigations for research and applications, International Journal of Production Economics 140(1): 35-47. http://dx.doi.org/10.1016/j.ijpe.2011.05.011

Hashemkhani Zolfani, S.; Chen, I. S.; Rezaeiniya, N.; Tamošaitienė, J. 2012. A hybrid MCDM model encompassing AHP and COPRAS-G methods for selecting company supplier in Iran, Technological and Economic Development of Economy 18(3): 529-543.

http://dx.doi.org/10.3846/20294913.2012.709472 
Hashemkhani Zolfani, S.; Maknoon, R.; Zavadskas, E. K. 2016(a). An introduction to prospective multiple attribute decision making (PMADM), Technological and Economic Development of Economy 22(2): 309-326. http://dx.doi.org/10.3846/20294913.2016.1150363

Hashemkhani Zolfani, S.; Maknoon, R.; Zavadskas, E. K. 2016(b). Multiple attribute decision making (MADM) based scenarios, International Journal of Strategic Property Management 20(1): 101-111. http://dx.doi.org/10.3846/1648715X.2015.1132487

Hashemi, S. H.; Karimi, A.; Tavana, M. 2015. An integrated green supplier selection approach with analytic network process and improved Grey relational analysis, International Journal of Production Economics 159: 178-191. http://dx.doi.org/10.1016/j.ijpe.2014.09.027

Hatami-Marbini, A.; Tavana, M. 2011. An extension of the Electre I method for group decisionmaking under a fuzzy environment, Omega 39(4): 373-386.

http://dx.doi.org/10.1016/j.omega.2010.09.001

HooBae, S.; Sarkis, J.; SikYoo, C. 2011. Greening transportation fleets: insights from a two-stage game theoretic model, Transportation Research Part E: Logistics and Transportation Review 47(6): 793-807. http://dx.doi.org/10.1016/j.tre.2011.05.015

Kahraman, C.; Cebeci, U.; Ulukan, Z. 2003. Multi-criteria supplier selection using fuzzy AHP, Logistics Information Management 16(6): 382-394. http://dx.doi.org/10.1108/09576050310503367

Karande, P.; Chakraborty, S. 2012. Application of multi-objective optimization on the basis of ratio analysis (MOORA) method for materials selection, Materials \& Design 37: 317-324.

http://dx.doi.org/10.1016/j.matdes.2012.01.013

Khademi-Zare, H.; Zarei, M.; Sadeghieh, A.; Owlia, M. S. 2010. Ranking the strategic actions of Iran mobile cellular telecommunication using two models of fuzzy QFD, Telecommunications Policy 34(11): 747-759. http://dx.doi.org/10.1016/j.telpol.2010.10.001

Kwong, C. K.; Bai, H. 2002. A fuzzy AHP approach to the determination of importance weights of customer requirements in quality function deployment, Journal of Intelligent Manufacturing 13(5): 367-377. http://dx.doi.org/10.1023/A:1019984626631

Kilincci, O.; Onal, S. A. 2011. Fuzzy AHP approach for supplier selection in a washing machine company, Expert systems with Applications 38(8): 9656-9664.

http://dx.doi.org/10.1016/j.eswa.2011.01.159

Lixin, D.; Ying, L.; Zhiguang, Z. 2008. Selection of logistics service provider based on analytic network process and VIKOR algorithm, in Networking, Sensing and Control, 2008. ICNSC 2008, IEEE International Conference, 6-8 April 2008, Sanya, China, 1207-1210.

Lee, A. H.; Kang, H. Y.; Hsu, C. F.; Hung, H. C. 2009. A green supplier selection model for high-tech industry, Expert Systems with Applications 36(4): 7917-7927.

http://dx.doi.org/10.1016/j.eswa.2008.11.052

Min, H.; Kim, H. 2012. Green supply chain research: past, present, and future, Logistics Research 4: 39-47. http://dx.doi.org/10.1007/s12159-012-0071-3

Pi, W. N.; Low, C. 2006. Supplier evaluation and selection via Taguchi loss functions and an AHP, The International Journal of Advanced Manufacturing Technology 27(5-6): 625-630.

http://dx.doi.org/10.1007/s00170-004-2227-z

Rajesh, G.; Malliga, P. 2013. Supplier selection based on AHP QFD Methodology, Procedia Engineering 64: 1283-1292. http://dx.doi.org/10.1016/j.proeng.2013.09.209

Sanayei, A.; Mousavi, S. F.; Yazdankhah, A. 2010. Group decision making process for supplier selection with VIKOR under fuzzy environment, Expert Systems with Applications 37(1): 24-30. http://dx.doi.org/10.1016/j.eswa.2009.04.063

Sarkis, J.; Zhu, Q.; Lai, K. 2011. An organizational theoretic review of green supply chain management literature, International Journal of Production Economics 130(1): 1-15.

http://dx.doi.org/10.1016/j.ijpe.2010.11.010 
Shabani, A.; Farzipoor Saen, R.; Torabipour, S. M. R. 2014. A new data envelopment analysis (DEA) model to select eco-efficient technologies in the presence of undesirable outputs, Clean Technologies and Environmental Policy 16(3): 513-525. http://dx.doi.org/10.1007/s10098-0130652-0

Stanujkic, D.; Karabasevic, D.; Zavadskas, E. K. 2015. A framework for the selection of a packaging design based on the SWARA method, Inzinerine Ekonomika-Engineering Economics 26(2): 181-187. http://dx.doi.org/10.5755/j01.ee.26.2.8820

Vachon, S.; Klassen, R. D. 2006. Extending green practices across the supply chain: the impact of upstream and downstream integration, International Journal of Operations \& Production Management 26(7): 795-821. http://dx.doi.org/10.1108/01443570610672248

Vafaeipour, M.; Zolfani, S. H.; Varzandeh, M. H. M.; Derakhti, A.; Eshkalag, M. K. 2014. Assessment of regions priority for implementation of solar projects in Iran: new application of a hybrid multi-criteria decision making approach, Energy Conversion and Management 86: 653-663. http://dx.doi.org/10.1016/j.enconman.2014.05.083

Varsei, M.; Soosay, C.; Fahimnia, B.; Sarkis, J. 2014. Framing sustainability performance of supply chains with multidimensional indicators, Supply Chain Management: an International Journal 19: 242-257. http://dx.doi.org/10.1108/SCM-12-2013-0436

Xia, W.; Wu, Z. 2007. Supplier selection with multiple criteria in volume discount environments, Omega 35(5): 494-504. http://dx.doi.org/10.1016/j.omega.2005.09.002

Yang, C. C.; Chen, B. S. 2006. Supplier selection using combined analytical hierarchy process and grey relational analysis, Journal of Manufacturing Technology Management 17(7): 926-941. http://dx.doi.org/10.1108/17410380610688241

Yang, C. H.; Lu, C. S.; Haider, J. J.; Marlow, P. B. 2013. The effect of green supply chain management on green performance and firm competitiveness in the context of container shipping in Taiwan, Transportation Research Part E: Logistics and Transportation Review 55: 55-73. http://dx.doi.org/10.1016/j.tre.2013.03.005

Yang, J. L.; Tzeng, G. H. 2011. An integrated MCDM technique combined with DEMATEL for a novel cluster-weighted with ANP method, Expert Systems with Applications 38(3): 1417-1424. http://dx.doi.org/10.1016/j.eswa.2010.07.048

Yazdani, M.; Graeml, F. R. 2014. VIKOR and its applications: a state-of-the-art survey, International Journal of Strategic Decision Sciences (IJSDS) 5(2): 56-83.

http://dx.doi.org/10.4018/ijsds.2014040105

Yazdani, M.; Payam, A. F. 2015. A comparative study on material selection of micro electromechanical systems electrostatic actuators using Ashby, VIKOR and TOPSIS, Materials \& Design 65: 328-334. http://dx.doi.org/10.1016/j.matdes.2014.09.004

Zavadskas, E. K.; Vilutienė, T. 2006. A multiple criteria evaluation of multi-family apartment block's maintenance contractors: I-model for maintenance contractor evaluation and the determination of its selection criteria, Building and environment 41(5): 621-632.

http://dx.doi.org/10.1016/j.buildenv.2005.02.019

Zavadskas, E. K.; Turskis, Z.; Tamošaitiene, J. 2010. Risk assessment of construction projects, Journal of Civil Engineering and Management 16(1): 33-46.

http://dx.doi.org/10.3846/jcem.2010.03

Zavadskas, E. K.; Kaklauskas, A.; Turskis, Z.; Tamošaitiene, J. 2008. Selection of the effective dwelling house walls by applying attributes values determined at intervals, Journal of Civil Engineering and Management 14(2): 85-93. http://dx.doi.org/10.3846/1392-3730.2008.14.3

Zavadskas, E. K.; Turskis, Z.; Antucheviciene, J.; Zakarevicius, A. 2012. Optimization of weighted aggregated sum product assessment, Elektronika ir elektrotechnika 122(6): 3-6.

http://dx.doi.org/10.5755/j01.eee.122.6.1810 
Zhu, Q.; Sarkis, J.; Lai, K. 2006. Green supply chain management: pressures, practices and performance within the Chinese automobile industry, Journal of Cleaner Production 15(11-12): 1041-1052. http://dx.doi.org/10.1016/j.jclepro.2006.05.021

Zhu, Q.; Sarkis, J.; Lai, K. 2008. Confirmation of a measurement model for green supply chain management practices implementation, International Journal of Production Economics 111(2): 261-273. http://dx.doi.org/10.1016/j.ijpe.2006.11.029

Morteza YAZDANI is a PhD Scholar of Business Economic at the Universidad Europea de Madrid, Spain. His main research interests are the application of multi-criteria decision making in different fields as material science, supply chain management, construction management and also strategic planning. He is a member of the editorial board of the International Journal of Business and Systems research (INDERSCIENCE) and a reviewer of the journal "Sustainability". His work has been published in top international journals such as Journal of Civil Engineering and Management, Technological and Economic Development of Economy, Expert Systems with Applications, Materials and Design and International Journal of Logistics Research and applications.

Sarfaraz HASHEMKHANI ZOLFANI is a PhD student of the Technology Foresight in Amirkabir University of Technology (Tehran Polytechnic). He works at the Futures Studies Research Institute of Amirkabir University of Technology (Tehran Polytechnic), the Sustainability Office of Amirkabir University of Technology (Tehran Polytechnic) and the Research Institute of the Internet and Intelligent Technologies of Vilnius Gediminas Technical University. He is a member of EURO Working Group OR in Sustainable Development and Civil Engineering. He is a reviewer for a number of journals, such as the International Journal of Strategic Property Management, International Journal of Environmental Research, Journal of Applied Mathematics, etc. He is an author of more than 50 scientific papers that have been presented, published or reviewed at/for International Conferences and Journals (including ISI-cited publications). His work has been published in a number of journals, such as Expert Systems With Applications, Energy Conversion and Management, Technological and Economic Development of Economy, Journal of Business Economics and Management, International Journal of Strategic Property Management, Archives of Civil and Mechanical Engineering, Transport, The Baltic Journal of Road and Bridge Engineering, etc. His research interests include: performance evaluation, strategic management, decision-making theory, supply chain management, (dynamic) multi criteria decision making, future studies, sustainable development and game theory.

Edmundas Kazimieras ZAVADSKAS. PhD, DrSc, H.C. mult. Prof., the Head of the Department of Construction Technology and Management at Vilnius Gediminas Technical University, Lithuania. He is a Senior Research Fellow at the Research Institute of Smart Building Technologies. PhD in Building Structures (1973) and DrSc in Building Technology and Management (1987). A member of Lithuanian and several foreign Academies of Sciences. Doctore Honoris Causa from Poznan, Saint Petersburg and Kiev universities. Honorary International Chair Professor of the National Taipei University of Technology. A member of international organisations; a member of steering and programme committees at many international conferences; a member of the editorial boards of several research journals; the author and co-author of more than 400 papers and a number of monographs in Lithuanian, English, German and Russian. The editor-in-chief of journals Technological and Economic Development of Economy and Journal of Civil Engineering and Management. Research interests: building technology and management, decision-making theory, automation in design and decision support systems. 